\title{
Frequency of ABO and Rhesus blood groups in Saudi healthy blood donors versus non-Saudi in a retrospective study in Makkah City
}

\author{
Amal Zaghloul ${ }^{1,2}$, Mohammad Aldosari ${ }^{3}$, Talat. Al-bukhari ${ }^{2}$, Yonis Allohibi ${ }^{2}$,Shirin Teama ${ }^{1,3}$, Ghada Wassif ${ }^{4}$, Iman \\ Osheba $^{3,5}$, Nada Bajafier ${ }^{2}$.
}

${ }^{1}$ Clinical Pathology Department, Faculty of Medicine, Ain Shams University, Egypt.

${ }^{2}$ Hematology and Immunology Department, Faculty of Medicine, Umm Al Qura University, KSA.

${ }^{3}$ Department of laboratory, King Abdulaziz Hospital, Ministry of Health, Makkah, KSA.

${ }^{4}$ Department of Anatomy, Faculty of Medicine, Taibah University, Al Madinah Al Munawarah, KSA.

${ }^{5}$ Clinical Pathology Department, national liver institute, Egypt.

\section{ABSTRACT}

Purpose: to assess the frequency of $\mathrm{ABO}$ and Rh blood groups among Saudi and non-Saudi healthy blood donors and to compare between them.

Methods: A retrospective study was conducted; in Makkah City, Saudi Arabia. It included 15,365 participants of 44 nationalities who have attended the blood bank of King Abdul Aziz Hospital. The collected data were age, sex, nationality, ABO, and Rhesus blood groups.

Results: $46.8 \%$ of the participants were O, $28.8 \%$ A, $19.5 \%$ B, and $4.9 \%$ AB. The nationalities with a higher frequency of blood group O were Saudi, Mauritanian, Yemeni, Thai, Malian, Sudanese, Jordanian, Indian, Moroccan, Somali, Malaysian, Indonesian, Myanmar, Nigerian, Pakistani, Bangladeshi, Algerian, Djibouti, Burkinabe, Eritrean, Ghanaian, Bahraini, Bosnian, Canadian, Gambian, Iraqi, and Sri Lankan. Those with a higher frequency of blood group A were Turkish, Palestinian, Syrian, Lebanese, Egyptian, Afghan, Chadian, French, Tunisian, Cameroonian, Ethiopian, and British. Those with a higher frequency of B were Nigerien, American, Nepalese, and two nationalities with higher AB frequency Filipino and Chinese. $91.6 \%$ of all populations were Rh-positive, and $8.4 \%$ were Rh-negative. The Saudi participants were like some nationalities and differed from others.

Conclusion: In Makkah city, the higher frequency of ABO blood group in Saudi and non -Saudi people is O followed by A, then B, and $\mathrm{AB}$. The Rh-positive is predominant, and $8.4 \%$ of the participants are negative. The ABO and Rh blood groups' identifications are essential for providing suitable blood storage for individuals in need.

Keyword: ABO, Rh, blood groups, Saudi, non-Saudi.

\section{Introduction}

The $\mathrm{ABO}$ and Rhesus (Rh) blood groups are the most common blood group antigens. The ABO is divided into $\mathrm{A}, \mathrm{B}, \mathrm{O}$, and $\mathrm{AB}[1,2]$, according to the antigens present on the extra cellular surface of red blood cells (RBC). The $\mathrm{O}$ blood group has $\mathrm{H}$ antigen on its surface. The $\mathrm{A}, \mathrm{B}$, and $\mathrm{AB}$ have some oligosaccharides residues added to the $\mathrm{H}$ antigen, resulting in groups $\mathrm{A}$, $\mathrm{B}$, and $\mathrm{AB}[3,4]$. The $\mathrm{ABO}$ antigens are also present

\begin{tabular}{|l|l|}
\hline \multicolumn{2}{|c|}{ Access this article online } \\
\hline Quick Response Code: & Website: \\
& www.smh-j.com \\
\cline { 2 - 2 } & DOI: \\
\hline
\end{tabular}

On the surface of cells and tissues in most persons [5]. The Rh blood type is the second blood group in its importance in transfusion medicine. It is highly polymorphic as it contains more than 44 different antigens. Rh antigens inheritance is determined by a complex of two closely linked genes: one encodes the $\mathrm{D}$ antigen, the other encodes the $\mathrm{C}$ or $\mathrm{c}$, and $\mathrm{E}$ or $\mathrm{e}$ antigens [6].

Address for correspondence: Amal Zaghloul, Clinical Pathology Department, Faculty of Medicine, Ain Shams University, Egypt.

E-mail: amalzaghloul1@ @otmail.com

Received: 30 September $2021 \mid$ Accepted: 19 November 2021

This is an open access article by SMHJ is licensed under Creative Commons Attribution 4.0 International License.

(https://creativecommons.org/licenses/by/4.0)

Please cite this article as: moustafa amal z., Aldosari MS, AL-Bukhari TA, Allohibi YA, Teama SH ., Wassif GA, Osheba IS, bajuaifer N. The Frequency of ABO and Rhesus blood groups in Saudi healthy blood donors versus non-Saudi in a retrospective study in Makkah City: $\mathrm{ABO}$ and Rhesus blood groups in Makkah City. SMHJ [Internet]. 2021;1(1):2-13.

(C) Saudi Medical Horizons Journal

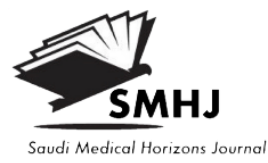




\section{Frequency of $A B O$ and Rhesus blood groups in Saudi healthy blood donors versus non-Saudi in a retrospective study in Makkah City}

The terms $\mathrm{Rh}$ positive and $\mathrm{Rh}$ negative refer to the presence or absence of D antigen [7, 8]. The frequency of these blood groups varies from one geographic location to another. This reflects human people underlying genetic and ethnic diversity and suggests that a particular blood group showed protection or selective advantage to certain diseases [9-12]. In different parts of the world, the $\mathrm{ABO}$ and $\mathrm{Rh}$ rate showed variations in blood groups frequency. Some areas with a higher frequency of $\mathrm{O}$, other of $\mathrm{A}$, and others of $\mathrm{B}$, and the Rh-positive is predominant [9, 1322]. In Saudi Arabia, many studies have been carried out on $\mathrm{ABO}$ and $\mathrm{Rh}$ frequency, with few in Makkah city which have many residents of different nationalities. Most of these studies were done on the Saudi population and reported that the blood group $\mathrm{O}$ is the predominant one, followed by $\mathrm{A}, \mathrm{B}$, and $\mathrm{AB}$, and the Rh-positive is dominant except for the Hail province, which showed a group frequency of $\mathrm{O}>\mathrm{B}>\mathrm{A}>\mathrm{AB}$ [23-28]. The Aim of the study is to assess $\mathrm{ABO}$ and $\mathrm{Rh}$ blood groups frequency in Saudi and non-Saudi healthy blood donors in Makkah city and compare the frequency between different populations.

\section{Methods}

A retrospective cross-sectional study was conducted from April 2020 to January 2021 at the Hematology and Immunology Department of the Faculty of Medicine, Umm Al-Qura University, Makkah, Saudi Arabia. The data were collected from the blood bank of King Abdul Aziz hospital. The collected data were from January 2014 to August 2019. The biomedical ethics of the faculty of medicine of the Umm Al-Qura University approved the protocol of this study, and the approval number was HAPO-02-K-012-2020-05-385. The followings data were collected:

1- Sociodemographic character data, which include age, sex, and nationality.

2- The ABO and Rh blood groups. The automated and manual methods were used for determination of $\mathrm{ABO}$ and $\mathrm{Rh}$. The automated methods were the microplate or gel card [29-30]. In the microplate, the red cell suspension and monoclonal antibodies were pipetted onto a microwell plate and examined for agglutination. In reverse typing, the cells and patient's plasma were mixed and examined for agglutination. In the gel card (forward), the RBC suspension was added to the column, which contains antisera of $\mathrm{ABO} / \mathrm{Rh}$. After centrifugation, the cell pellet was either at the top (positive) or bottom (negative). The manual methods were used to resolve discrepancies or confirm negativity of $\mathrm{Rh}[31]$.
All participants who were fulfilling the national blood transfusion guidelines in Saudi Arabia were included. All persons who were rejected from the blood bank to donate blood were excluded.

\section{Statistical analysis}

This statistical analysis was done using the SPSS program version 20. Quantitative data was described in the form of mean $\pm \mathrm{SD}$. The numbers and percentage of participants and the blood groups were calculated. The comparison between groups was performed by using the Student t-test.

\section{Results:}

The results were summarized in (Tables 1-4) and (Figure 1). This study included 15,365 persons. They were 15,181 males and 184 females with a ratio of $82.5: 1$. The mean age was $31.8 \pm 8.9$ years, the median was 30 years, and their age ranged from 18 to 62 years. The nationality of the participants, their numbers, their age, and sex were showed in (Table1). There was a significant increase in the age between Saudi and Malian, Myanmar, and Pakistani and a significant decrease between the Egyptian people. The frequency of blood groups in all the populations studied was showed in (Table 2). Of all participants, $46.8 \%$ were O, $28.8 \%$ A, $19.5 \%$ B, and $4.9 \%$ AB. $91.6 \%$ were Rh-positive, and $8.4 \%$ were Rh-negative. The following nationalities had a higher frequency of blood group $\mathrm{O}$ with variations in other blood groups' order. The Mauritanian, Yemeni, Thai, Malian, Sudanese, Saudi, Jordanian, and Indian had a frequency of $\mathrm{O}>\mathrm{A}>\mathrm{B}>\mathrm{AB}$. The Moroccan showed $\mathrm{O}$ $>\mathrm{A}>\mathrm{B}=\mathrm{AB}$. The Somali revealed $\mathrm{O}>\mathrm{A}>\mathrm{AB}$ and the absence of $B$. The Malaysian showed $O>A=A B$ with the lack of B. The Indonesian, Myanmar, Nigerian, Pakistani, and Bangladeshi showed a frequency of $\mathrm{O}>\mathrm{B}>\mathrm{A}>\mathrm{AB}$. The Algerian and Djibouti showed $\mathrm{O}$ $>\mathrm{A}=\mathrm{B}=\mathrm{AB}$. The Burkinabe and Eritrean displayed $\mathrm{O}$ $>\mathrm{B}>\mathrm{A}$ with $\mathrm{AB}$ 's absence. The Ghanaian showed a frequency of $\mathrm{O}>\mathrm{B}$ and a lack of $\mathrm{A}$ and $\mathrm{AB}$. The Bahraini, Bosnian, Canadian, Gambian, Iraqi, and Sri Lankan showed $100 \%$ frequency of blood group O with the absence of other blood groups. In this study, some had a higher frequency of blood group A. The Turkish, Palestinian, Syrian, Lebanese, Egyptian, and Afghan had a frequency of $\mathrm{A}>\mathrm{O}>\mathrm{B}>\mathrm{AB}$. The Chadian revealed $\mathrm{A}>\mathrm{O}>\mathrm{AB}$ with an absence of $\mathrm{B}$. The French and Tunisian showed $100 \%$ frequency of blood group A. The Cameroonian showed $\mathrm{A}>\mathrm{AB}$ and the lack of $\mathrm{B}$ and $\mathrm{O}$. The Ethiopian had $\mathrm{A}=\mathrm{O}>\mathrm{B}>\mathrm{AB}$. The British had $\mathrm{A}=\mathrm{B}$ with an absence of $\mathrm{AB}$ and $\mathrm{O}$. Few populations showed a higher frequency of blood group B with discrepancies in other blood groups' 

retrospective study in Makkah City

arrangement. The Nigerien had $\mathrm{B}>\mathrm{O}>\mathrm{A}>\mathrm{AB}$. The American and Nepalese showed $\mathrm{B}>\mathrm{O}$ with an absence of $\mathrm{A}$ and $\mathrm{AB}$. The Filipino and Chinese populations showed a higher frequency of the $\mathrm{AB}$ blood group. The Filipino had $\mathrm{AB}>\mathrm{O}=\mathrm{B}>\mathrm{A}$ and the Chinese had $\mathrm{AB}$ with the absence of $\mathrm{A}, \mathrm{B}$, and $\mathrm{O}$. Comparing the frequency of blood groups in the Saudi population and other societies was shown in (Figure 1). There was a significant decrease in blood group A in the Saudi population compared to Tunisian, Syrian, Palestinian, and Egyptian. Also, there was a significant increase compared to Nigerian, Pakistani, Myanmar, Indonesian, and Bangladeshi. The remaining nationalities showed no significant difference in the frequency of the blood group A. Regarding blood group B; there was a significant decrease in blood group B of the Saudi population compared to Afghan, Bangladeshi, Egyptian, Indian, Myanmar, Nepalese, Nigerian, Nigerien, and Pakistani. In contrast, there was a significant increase to the Yemeni population. The remaining nationalities showed no significant difference in the frequency of blood group B. The comparison between the frequencies of blood group $\mathrm{AB}$ in the Saudi population showed a significant decrease compared to Afghan, Bangladeshi, Cameroonian, Chinese, Egyptian, Filipino, Indian, Nigerien, and Pakistani. Comparing the frequency of blood group $\mathrm{O}$ in the Saudi population showed a significant increase compared to Afghan, Bangladeshi, Egyptian, Indian, Myanmar, Pakistani, Palestinian, Syrian, and Tunisian. In contrast, there was a significant decrease when compared to Yemeni. The frequency of $\mathrm{Rh}$ of the different populations studied was shown in (Table 3). Some populations had $\mathrm{Rh}$ positive only: Algerian, American, Bahraini, Bosnian, British, Canadian, Chadian, Djibouti, Eritrean, Filipino, French, Gambian, Indonesian, Iraqi, Malaysian, Moroccan, Nepalese, Sri Lankan, and Thai. Other populations showed positive and negative $\mathrm{Rh}$ with the predominant of the positive $\mathrm{Rh}$. The highest frequency of $\mathrm{Rh}$ negativity were found in Tunisian (66.7\%), Chinese(50\%), Mauritanian(36.1\%), Cameroonian(33.3\%), Jordanian(16.1\%), Sudanese(14.9\%), Palestinian(14.7\%), Afghan(12.2\%), Saudi(8.6\%), Nigerien(8.3\%), Lebanese(8.3\%), Egyptian(8.1\%), Yemeni(8.1\%), Ethiopian(7.7\%), Pakistani(7.7\%), Malian(6.8\%), Turkish(5.7\%), Somali(5.6\%), Bangladeshi(5.4\%), Nigerian(5.2\%), Indian(5\%), Burkinabe(4.8\%) and Myanmar(3.2\%). Comparing the Rh-negative frequency in the different populations to the Saudi population showed a significant increase of the Rh negativity in Mauritanian, Sudanese, Syrian, and Tunisian $\mathrm{p}<0.05$. Moreover, the Saudi population showed a significant increase of $\mathrm{Rh}$ negativity than Myanmar and Nigerian $\mathrm{p}<0.05$. The remaining populations showed no significant difference compared to the Saudi population $\mathrm{p}>0.05$, (Table 3). The distributions of both the $\mathrm{ABO}$ and $\mathrm{Rh}$ in all populations studied were showed in (Table4).

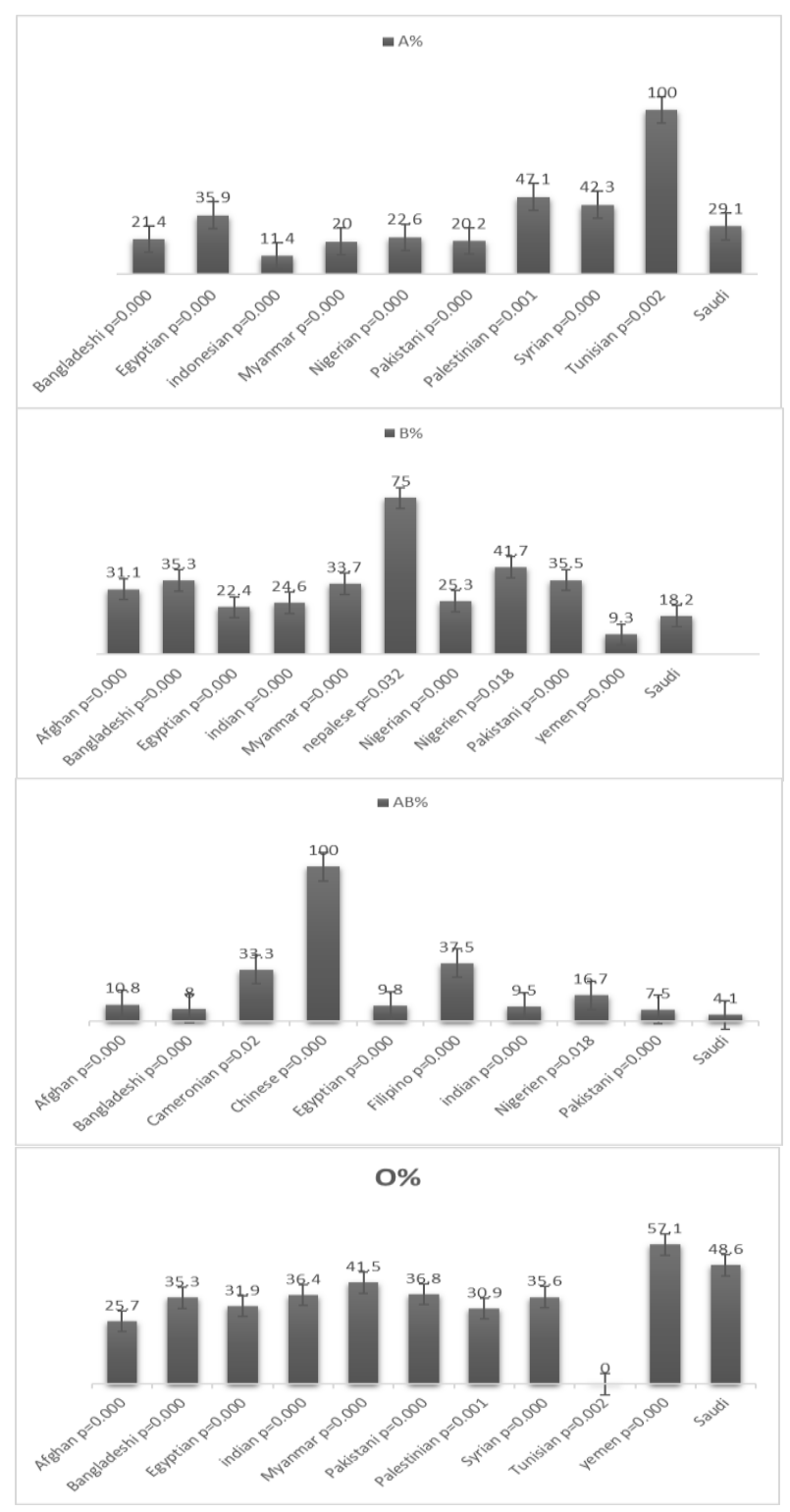

Figure 1: Comparison of the blood group $A, B, A B$ and $O$ between Saudi population and other populations. N.B. Nationality with significant difference were shown. 
Table 1: Sociodemographic characteristics of the participants.

\begin{tabular}{|c|c|c|c|c|c|c|c|c|c|}
\hline Nationality & no. & Age & & $x$ & Nationality & no. & Age & & \\
\hline & & & Male & female & & & & Male & female \\
\hline Afghan & 74 & $28.8 \pm 7.0$ & 73 & 1 & Iraqi & 1 & 34 & 1 & 0 \\
\hline Algerian & 6 & $34.2 \pm 14.1$ & 6 & 0 & Jordanian & 62 & $30.1 \pm 11.7$ & 61 & 1 \\
\hline American & 3 & $32.3 \pm 13.2$ & 3 & 0 & Lebanese & 12 & $35.8 \pm 14.6$ & 12 & 0 \\
\hline Bahraini & 2 & $45.0 \pm 9.9$ & 2 & 0 & Malaysian & 7 & $29.3 \pm 4.6$ & 7 & 0 \\
\hline Bangladeshi & 224 & $31.4 \pm 7.0$ & 224 & 0 & Malian & 176 & $29.9 \pm 7.0 * \mathrm{HS}$ & 176 & 0 \\
\hline Bosnian & 1 & 30 & 1 & 0 & Mauritanian & 36 & $28.2 \pm 10.5$ & 33 & 3 \\
\hline British & 2 & $37.5 \pm 14.8$ & 2 & 0 & Moroccan & 15 & $28.1 \pm 14.8$ & 15 & 0 \\
\hline Burkinabe & 21 & $28.0 \pm 7.5$ & 21 & 0 & Myanmar & 439 & $28.7 \pm 6.3 * \mathrm{HS}$ & 439 & 0 \\
\hline Cameroonian & 3 & $34.7 \pm 10.8$ & 3 & 0 & Nepalese & 4 & $25.5 \pm 1.3$ & 4 & 0 \\
\hline Canadian & 1 & 28 & 1 & 0 & Nigerian & 439 & $24.1 \pm 13.5 * \mathrm{HS}$ & 438 & 1 \\
\hline Chadian & 9 & $29.3 \pm 5.5$ & 9 & 0 & Nigerien & 12 & $33.0 \pm 6.5$ & 12 & 0 \\
\hline Chinese & 2 & $28.5 \pm 5.0$ & 2 & 0 & Pakistani & 853 & $29.6 \pm 7.1 * \mathrm{HS}$ & 350 & 3 \\
\hline Djibouti & 5 & $25.2 \pm 3.7$ & 5 & 0 & Palestinian & 68 & $27.4 \pm 12.5$ & 68 & 0 \\
\hline Egyptian & 1130 & $33.5 \pm 8.3 * \mathrm{HS}$ & 1128 & 2 & Saudi & 8554 & $31.9 \pm 9.5 * \mathrm{~S}$ & 8400 & 154 \\
\hline Eritrean & 10 & $28.3 \pm 9.8$ & 10 & 0 & Somali & 18 & $27.7 \pm 11.5$ & 18 & 0 \\
\hline Ethiopian & 39 & $29.4 \pm 10.3$ & 39 & 0 & Sudanese & 451 & $30.6 \pm 12.8$ & 451 & 0 \\
\hline Filipino & 8 & $34.6 \pm 7.3$ & 6 & 2 & Sri Lankan & 5 & $25.4 \pm 15.8$ & 5 & 0 \\
\hline French & 1 & 33 & 1 & 0 & Syrian & 430 & $33.1 \pm 12.5$ & 425 & 5 \\
\hline Gambian & 6 & $42.2 \pm 1.2$ & 6 & 0 & Thai & 68 & $27.0 \pm 14.0$ & 68 & 0 \\
\hline Ghanaian & 9 & $25.3 \pm 1.4$ & 9 & 0 & Tunisian & 6 & $26.5 \pm 11.1$ & 2 & 4 \\
\hline Indian & 220 & $28.8 \pm 12.3$ & 219 & 1 & Turkish & 35 & $28.0 \pm 19.0$ & 35 & 0 \\
\hline Indonesian & 44 & $29.5 \pm 13.9$ & 41 & 3 & Yemeni & 1854 & $29.9 \pm 11.1$ & 1850 & 4 \\
\hline Total & & & & & & 15365 & $31.8 \pm 8.9$ & 15.181 & 184 \\
\hline
\end{tabular}


Table 2: The distributions of the ABO blood group in different nationalities studied.

\begin{tabular}{cccccccccc}
\hline Nationality & $\mathbf{A \%}$ & $\mathbf{B} \%$ & $\mathbf{A B \%}$ & $\mathbf{O \%}$ & Nationality & $\mathbf{A \%}$ & $\mathbf{B \%}$ & $\mathbf{A B \%}$ & $\mathbf{0 \%}$ \\
\hline Turkish & 48.6 & 11.4 & 2.9 & 37.1 & Malaysian & 14.3 & 0 & 14.3 & 71.4 \\
\hline Palestinian & 47.1 & 13.2 & 8.8 & 30.9 & Indonesian & 11.4 & 27.3 & 9.1 & 52.3 \\
\hline Syrian & 42.3 & 17 & 5.1 & 35.6 & Myanmar & 20 & 33.7 & 4.8 & 41.5 \\
\hline Lebanese & 41.7 & 25 & 8.3 & 25 & Nigerian & 22.6 & 25.3 & 3.9 & 48.3 \\
\hline Egyptian & 35.9 & 22.4 & 9.8 & 31.9 & Pakistani & 20.2 & 35.5 & 7.5 & 36.8 \\
\hline Afghan & 32.4 & 31.1 & 10.8 & 25.7 & Bangladeshi & 21.4 & 35.3 & 8 & 35.3 \\
\hline Chadian & 44.4 & 0 & 22.2 & 33.3 & Algerian & 16.7 & 16.7 & 16.7 & 50 \\
\hline French & 100 & 0 & 0 & 0 & Djibouti & 20 & 20 & 20 & 40 \\
\hline Tunisian & 100 & 0 & 0 & 0 & Burkinabe & 14.3 & 38.1 & 0 & 47.6 \\
\hline Cameroonian & 66.7 & 0 & 33.3 & 0 & Eritrean & 20 & 40 & 0 & 40 \\
\hline Ethiopian & 35.9 & 23.1 & 5.1 & 35.9 & Ghanaian & 0 & 11.1 & 0 & 88.9 \\
\hline British & 50 & 50 & 0 & 0 & Bahraini & 0 & 0 & 0 & 100 \\
\hline Mauritanian & 16.7 & 11.1 & 2.8 & 69.4 & Bosnian & 0 & 0 & 0 & 100 \\
\hline Yemeni & 30.4 & 9.3 & 3.2 & 57.1 & Canadian & 0 & 0 & 0 & 100 \\
\hline Thai & 26.5 & 14.7 & 5.9 & 52.9 & Gambian & 0 & 0 & 0 & 100 \\
\hline Malian & 25.6 & 22.7 & 2.3 & 49.4 & Iraqi & 0 & 0 & 0 & 100 \\
\hline Sudanese & 25.7 & 20.4 & 4.7 & 49.2 & Sri Lankan & 0 & 0 & 0 & 100 \\
\hline Saudi & 29.1 & 18.2 & 4.1 & 48.6 & Nigerien & 16.7 & 41.7 & 16.7 & 25 \\
\hline Jordanian & 32.3 & 22.6 & 1.6 & 43.5 & American & 0 & 66.7 & 0 & 33.3 \\
\hline Indian & 27.7 & 24.6 & 9.5 & 36.4 & Nepalese & 0 & 75 & 0 & 25 \\
\hline Moroccan & 26.7 & 6.7 & 6.7 & 60 & Filipino & 12.5 & 25 & 37.5 & 25 \\
\hline Somali & 27.8 & 0 & 11.1 & 61.1 & Chinese & 0 & 0 & 100 & 0 \\
\hline
\end{tabular}


Table 3: The comparison of the frequency of Rh in different populations versus Saudi populations.

\begin{tabular}{llllllllllll}
\hline Nationality & No. & \multicolumn{2}{l}{ Positive } & \multicolumn{2}{c}{ Negative } & Nationality & No. & \multicolumn{2}{c}{ Positive } & \multicolumn{2}{c}{ Negative } \\
\hline & & $\mathrm{N}$ & $\%$ & $\mathrm{~N}$ & $\%$ & & & $\mathrm{~N}$ & $\%$ & $\mathrm{~N}$ & $\%$ \\
\hline Afghan & 74 & 65 & 87.8 & 9 & 12.2 & Iraqi & 1 & 1 & 100 & 0 & 0 \\
\hline Algerian & 6 & 6 & 100 & 0 & 0 & Jordanian & 62 & 52 & 83.9 & 10 & $16 . *^{*} \mathrm{~S}$ \\
\hline American & 3 & 3 & 100 & 0 & 0 & Lebanese & 12 & 11 & 91.7 & 1 & 8.3 \\
\hline Bahraini & 2 & 2 & 100 & 0 & 0 & Malaysian & 7 & 7 & 100 & 0 & 0 \\
\hline Bangladeshi & 224 & 212 & 94.6 & 12 & 5.4 & Malian & 176 & 164 & 93.2 & 12 & 6.8 \\
\hline Bosnian & 1 & 1 & 100 & 0 & 0 & Mauritanian & 36 & 23 & 63.9 & 13 & $36.1^{*} \mathrm{HS}$ \\
\hline British & 2 & 2 & 100 & 0 & 0 & Moroccan & 15 & 15 & 100 & 0 & 0 \\
\hline Burkinabe & 21 & 20 & 95.2 & 1 & 4.8 & Myanmar & 439 & 425 & 96.8 & 14 & $3.2 * \mathrm{HS}$ \\
\hline Cameroonian & 3 & 2 & 66.7 & 1 & 33.3 & Nepalese & 4 & 4 & 100 & 0 & 0 \\
\hline Canadian & 1 & 1 & 100 & 0 & 0 & Nigerian & 439 & 416 & 94.8 & 23 & $5.2 * \mathrm{~S}$ \\
\hline Chadian & 9 & 9 & 100 & 0 & 0 & Nigerien & 12 & 11 & 91.7 & 1 & 8.3 \\
\hline Chinese & 2 & 1 & 50 & 1 & 50 & Pakistani & 853 & 787 & 92.3 & 66 & 7.7 \\
\hline Djibouti & 5 & 5 & 100 & 0 & 0 & Palestinian & 68 & 58 & 85.3 & 10 & 14.7 \\
\hline Egyptian & 1130 & 1039 & 91.9 & 91 & 8.1 & Saudi & 8554 & 7817 & 91.4 & 737 & 8.6 \\
\hline Eritrean & 10 & 10 & 100 & 0 & 0 & Somali & 18 & 17 & 94.4 & 1 & 5.6 \\
\hline Ethiopian & 39 & 36 & 92.3 & 3 & 7.7 & Soudanese & 451 & 384 & 85.14 & 67 & $14.86^{*} \mathrm{HS}$ \\
\hline Filipino & 8 & 8 & 100 & 0 & 0 & Sri Lankan & 5 & 5 & 100 & 0 & 0 \\
\hline French & 1 & 1 & 100 & 0 & 0 & Syrian & 430 & 378 & 87.9 & 52 & $12.1 * \mathrm{~S}$ \\
\hline Gambian & 6 & 6 & 100 & 0 & 0 & Thai & 68 & 68 & 100 & 0 & 0 \\
\hline Ghanaian & 9 & 9 & 100 & 0 & 0 & Tunisian & 6 & 2 & 33.3 & 4 & $66.7^{*}$ HS \\
\hline Indian & 220 & 209 & 95 & 11 & 5 & Turkish & 35 & 33 & 94.3 & 2 & 5.7 \\
\hline Indonesian & 44 & 44 & 100 & 0 & $0 * \mathrm{~S}$ & Yemeni & 1854 & 1704 & 91.9 & 150 & 8.1 \\
\hline
\end{tabular}


Frequency of $A B O$ and Rhesus blood groups in Saudi healthy blood donors versus non-Saudi in a retrospective study in Makkah City

Table 4: The distributions of the ABO and Rh blood group in different nationality studied.

\begin{tabular}{|c|c|c|c|c|c|c|c|c|c|c|c|c|c|c|c|}
\hline \multirow{2}{*}{$\begin{array}{l}\text { ABO, } \\
\text { Rh } \\
\text { Nation } \\
\text { ality }\end{array}$} & \multicolumn{2}{|c|}{$\mathrm{A} \%$} & \multicolumn{2}{|c|}{ В\% } & \multicolumn{2}{|c|}{ AB $\%$} & \multicolumn{2}{|c|}{$0 \%$} & \multirow{2}{*}{$\begin{array}{l}\text { ABO, } \\
\text { Rh } \\
\text { Natio } \\
\text { nality }\end{array}$} & \multicolumn{2}{|c|}{ A\% } & \multicolumn{2}{|c|}{ B\% } & $\mathrm{AB} \%$ & $0 \%$ \\
\hline & $\begin{array}{c}+\mathrm{v} \\
\mathrm{e}\end{array}$ & ve & $\begin{array}{c}+\mathrm{v} \\
\mathrm{e}\end{array}$ & - & $\begin{array}{c}+\mathrm{v} \\
\mathrm{e}\end{array}$ & $\begin{array}{l}- \\
\mathrm{v}\end{array}$ & $\begin{array}{l}+ \\
\text { ve }\end{array}$ & ve & & $\begin{array}{c}+\mathrm{v} \\
\mathrm{e}\end{array}$ & ve & $\begin{array}{l}+ \\
\text { ve }\end{array}$ & ve & $\begin{array}{cc}+ & - \\
\text { ve } & \text { ve }\end{array}$ & $\begin{array}{c}+\mathrm{V} \\
\mathrm{e}\end{array}$ \\
\hline
\end{tabular}

$\begin{array}{llllllllllllllllll}\text { Afghan } & 27 & 5 . & 27 & 4 . & 10 & 0 & 23 & 2 . & \text { Pakist } & 18 & 1 . & 32 & 2 . & 6 . & 0 . & 34 . & 2 .\end{array}$

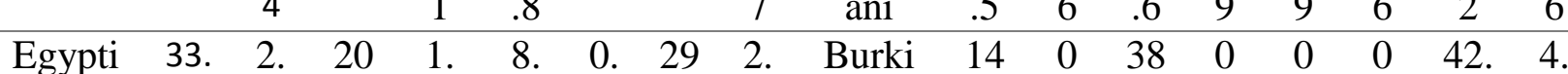
$\begin{array}{lllllllllllllll}\text { an } & 2 & 7 & .6 & 8 & 9 & 9 & .2 & 7 & \text { nabe } & .3 & .1 & 9 & 8\end{array}$

$\begin{array}{llllllllllllllllll}\text { Lebane } & 33 & 8 . & 21 & 3 . & 8 . & 0 & 25 & 0 & \text { Eritre } & 20 & 0 & 40 & 0 & 0 & 0 & 40 & 0\end{array}$ $\begin{array}{llllllll}\text { se } & .3 & 3 & .8 & 2 & 3 & \text { an }\end{array}$

$\begin{array}{llllllllllllllllll}\text { Palesti } & 44 & 2 . & 11 & 1 . & 5 . & 2 . & 23 & 7 . & \text { Ghana } & 0 & 0 & 11 & 0 & 0 & 0 & 88 . & 0\end{array}$ $\begin{array}{lllllllllllll}\text { nian } & .1 & 9 & .8 & 5 & 9 & 9 & .5 & 4 & \text { ian } & .1 & 9\end{array}$

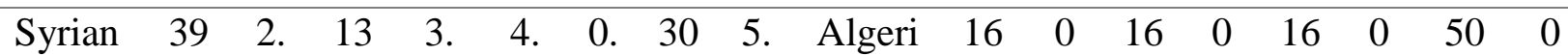
$\begin{array}{llllllllllll}.5 & 8 & .5 & 5 & 7 & 5 & .2 & 3 & \text { an } & .7 & .7 & .7\end{array}$

$\begin{array}{llllllllllllllllll}\text { Turkis } & 45 & 2 . & 8 . & 2 . & 2 . & 0 & 37 & 0 & \text { Djibo } & 20 & 0 & 20 & 0 & 20 & 0 & 40 & 0\end{array}$ $\begin{array}{lllllllll}\text { h } & .7 & 9 & 6 & 9 & 9 & .1 & \text { uti }\end{array}$

$\begin{array}{llllllllllllllllll}\text { Chadia } & 44 & 0 & 0 & 0 & 22 & 0 & 33 & 0 & \text { Ethiop } & 35 & 0 & 20 & 2 . & 2 . & 2 . & 33 . & 2 .\end{array}$ $\begin{array}{llllllllllll}\mathrm{n} & .4 & .2 & .3 & \text { ian } & .9 & .5 & 6 & 6 & 6 & 3 & 6\end{array}$

$\begin{array}{llllllllllllllllll}\text { Indian } & 24 & 3 . & 23 & 0 . & 9 . & 0 & 35 & 0 . & \text { Bahrai } & 0 & 0 & 0 & 0 & 0 & 0 & 10 & 0\end{array}$

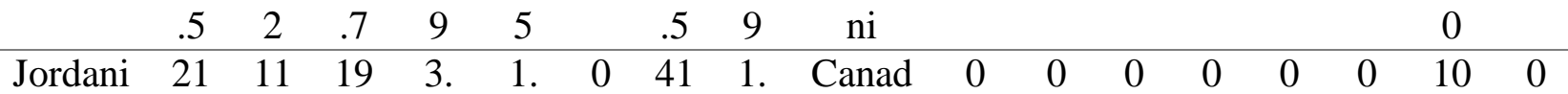
$\begin{array}{llllllllll}\text { an } & .3 & .4 & 2 & 6 & .9 & 6 & \text { ian } & 0\end{array}$

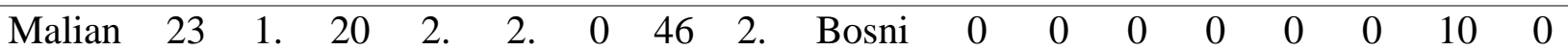
$\begin{array}{ccccccccccccccccccc} & .9 & 7 & .5 & 3 & 3 & & .6 & 8 & \text { an } & & & & & \\ \text { Maurit } & 13 & 2 . & 11 & 0 & 2 . & 0 & 36 & 33 & \text { Sri } & 0 & 0 & 0 & 0 & 0 & 0 & 10 & 0\end{array}$ $\begin{array}{lllllllll}\text { anian } & .9 & 8 & .1 & 8 & .1 & .3 & \text { Lanka }\end{array}$

$\begin{array}{llllllllllllllllll}\text { Saudi } & 26 & 2 . & 16 & 1 . & 3 . & 0 . & 44 & 4 . & \text { Iraqi } & 0 & 0 & 0 & 0 & 0 & 0 & 10 & 0\end{array}$ $\begin{array}{llllllll}.8 & 3 & .7 & 5 & 6 & 5 & .3 & 3\end{array}$

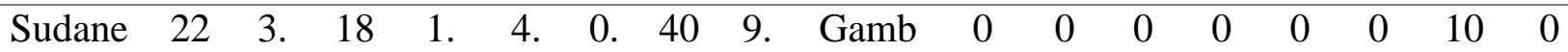
$\begin{array}{llllllllllll}\text { se } & .2 & 5 & .6 & 8 & 2 & 4 & .1 & 1 & \text { ian } & 0\end{array}$

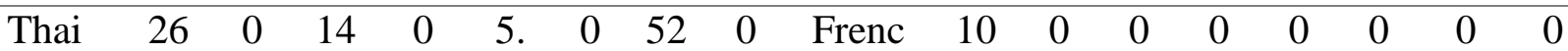

$\begin{array}{lllllll}.5 & .7 & 9 & .9 & \mathrm{~h} & 0\end{array}$

$\begin{array}{llllllllllllllllll}\text { Yemen } & 27 & 2 . & 8 . & 0 . & 2 . & 0 . & 52 & 4 . & \text { Tunisi } & 33 & 66 & 0 & 0 & 0 & 0 & 0 & 0\end{array}$ $\begin{array}{llllllllllll}\mathrm{i} & .8 & 6 & 7 & 6 & 9 & 3 & .5 & 6 & \text { an } & .3 & .7\end{array}$

$\begin{array}{llllllllllllllllll}\text { Moroc } & 26 & 0 & 6 . & 0 & 6 . & 0 & 60 & 0 & \text { Nigeri } & 16 & 0 & 41 & 0 & 16 & 0 & 16 . & 8 .\end{array}$

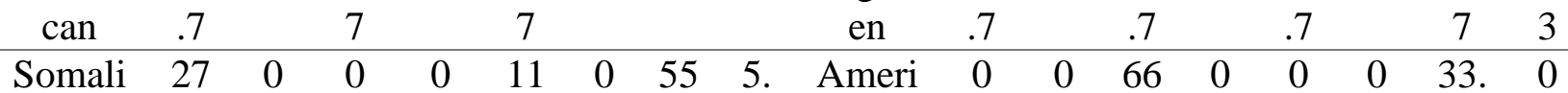

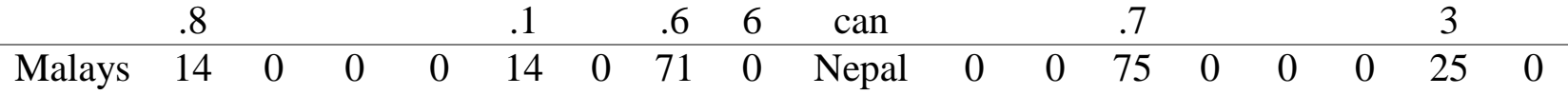
$\begin{array}{lllll}\text { ian } & .3 & .3 & .4 & \text { ese }\end{array}$

$\begin{array}{llllllllllllllllll}\text { Bangla } & 20 & 0 . & 31 & 3 . & 8 & 0 & 34 & 0 . & \text { Britis } & 50 & 0 & 50 & 0 & 0 & 0 & 0 & 0\end{array}$ $\begin{array}{llllllll}\text { deshi } & .5 & 9 & .7 & 6 & .4 & 9 & \mathrm{~h}\end{array}$

$\begin{array}{llllllllllllllllll}\text { Indone } & 11 & 0 & 27 & 0 & 9 . & 0 & 52 & 0 & \text { Camer } & 33 & 33 & 0 & 0 & 33 & 0 & 0 & 0\end{array}$ $\begin{array}{llllllllll}\operatorname{sian} & .4 & .3 & 1 & .3 & \text { oonia } & .4 & .3 & .3\end{array}$

$\begin{array}{llllllllllllllllll}\text { Myan } & 18 & 1 . & 32 & 0 . & 4 . & 0 . & 40 & 0 . & \text { Filipi } & 12 & 0 & 25 & 0 & 37 & 0 & 25 & 0\end{array}$ $\begin{array}{lllllllllllll}\operatorname{mar} & .7 & 4 & .8 & 9 & 6 & 2 & .8 & 9 & \text { no } & .5 & .5\end{array}$

$\begin{array}{llllllllllllllllll}\text { Nigeria } & 21 & 0 . & 23 & 1 . & 3 . & 0 & 44 & 2 . & \text { Chine } & 0 & 0 & 0 & 0 & 50 & 50 & 0 & 0\end{array}$ $\begin{array}{lllllllll}\mathrm{n} & .6 & 7 & .7 & 6 & 9 & .9 & 9 & \mathrm{se}\end{array}$ 


\section{Frequency of $\mathrm{ABO}$ and Rhesus blood groups in Saudi healthy blood donors versus non-Saudi in a retrospective study in Makkah City}

\section{Discussion}

This retrospective study was done in Makkah city on healthy blood donors (Saudi and non-Saudi). $98.8 \%$ were male, and $1.2 \%$ were female. This is because there is no good awareness in females about blood donation or they are not accepted as blood donors because of anemia [32]. The blood donors' age ranged from 18 to 62 years, which is accepted for blood donation [33]. The significant difference in the age between Saudi and non-Saudi is of no importance as all matching the accepted age for donations. The Saudi population showed a frequency of $\mathrm{O}>\mathrm{A}>\mathrm{B}>\mathrm{AB}$. This agrees with previous studies [23-27]. The Mauritanian, Yemeni, Thai, Malian, Sudanese, Jordanian, Indian, and Moroccan had the same incidence of $\mathrm{ABO}$ as the Saudi population. This is in accordance with previous studies with few discrepancies [14, 18-19, 22, 34-40]. In India, certain regions had a higher frequency of $\mathrm{O}$ and others of $\mathrm{B}$ or $\mathrm{A}[18,22,41]$. In Thailand, the frequency was $\mathrm{O}>\mathrm{B}>\mathrm{A}>\mathrm{AB}$ and not $\mathrm{O}>\mathrm{A}>\mathrm{B}>\mathrm{AB}[38,39]$. In Mali, some authors reported $\mathrm{O}>\mathrm{A}>\mathrm{B}>\mathrm{AB}$, and others $\mathrm{O}>\mathrm{B}>\mathrm{A}>\mathrm{AB}[36,42]$. The Malaysian $(\mathrm{n}=7)$ and Somali $(n=18)$ had the frequency of $\mathrm{O}>\mathrm{A}>\mathrm{AB}$ with an absence of $B$ blood group. In Malaysia, the frequency was either $\mathrm{O}>\mathrm{B}>\mathrm{A}>\mathrm{AB}$ or $\mathrm{O}>\mathrm{A}>\mathrm{B}>\mathrm{AB}[43,44]$. In Somalia, the frequency was $\mathrm{O}>\mathrm{A}>\mathrm{B}>\mathrm{AB}$ [45]. The absence of blood group $B$ may be due to their small number. The Indonesian ( $n=44)$, Myanmar $(n=439)$, and Nigerian $(n=439)$ had the frequency of $\mathrm{O}>\mathrm{B}>\mathrm{A}>\mathrm{AB}$, which agrees [46-48], and disagrees [49, 50], with their countries results. In Indonesia, the frequency was $\mathrm{B}>\mathrm{O}>\mathrm{AB}>\mathrm{A}$ [49], and in Nigeria, it was $\mathrm{O}>\mathrm{A}>\mathrm{B}>\mathrm{AB}[50]$. This may be explained by that these countries have different ethnic's origins. In Pakistan, the frequency was either $\mathrm{B}>\mathrm{O}>\mathrm{A}>\mathrm{AB}$ or $\mathrm{A}>\mathrm{O}>\mathrm{B}>\mathrm{AB}[51,52]$, and both are in contrast to our results, which was $O>B>A>A B \quad(n=853)$. This because some people have higher blood group incidence than others. The Bangladeshi $(n=224)$ showed $\mathrm{O}=\mathrm{B}>\mathrm{A}>\mathrm{AB}$. This is similar to the results done in Bangladesh [17], which reported a higher frequency of either $O$ or $B$. The Algerian $(n=6)$ and Djibouti $(n=5)$ had the frequency of $O>A=B=A B$. It agrees with previous studies in Algeria, but no studies were found for Djibouti. In Algeria, the frequency was either $\mathrm{O}>\mathrm{A}>\mathrm{B}>\mathrm{AB}$, or $\mathrm{A}>\mathrm{O}>\mathrm{B}>\mathrm{AB}[53,54]$. The equal frequency of other blood groups in our work may be due to the small number of participants. The Burkinabe $(n=21)$ had $O>B>A$ with the absence of AB. This agrees with a study done in Burkina Faso [55], in the higher incidence of $\mathrm{O}$. The AB blood group is the least proportion of the ABO blood group. The Eritrean $(n=10)$ had $O=B>A$ with the $A B$ 's absence. There were no previous references about the $\mathrm{ABO}$ in Eritrea. However, it agrees with most African people, which have a higher incidence of $\mathrm{O}$ blood group [48, $50,55]$. The Ghanaian $(n=9)$ had $O>B$ with the absence of the A and AB. They were like their country in the higher frequency of $\mathrm{O}[20,21]$. The lack of other blood groups is due to their small number. The Bahraini ( $n=2)$, Canadian $(n=1)$, Boasian $(n=1)$, Sri Lanka $(n=5)$, Iraqi $(n=1)$, and Gambian $(n=6)$, all had frequency of $\mathrm{O}$ blood group only. This because they do not represent the whole population of their nationalities. They had a similar frequency as in their countries with some exception [56-62]. In Bosna, some districts had a higher frequency of $\mathrm{O}$, and others had of A [59]. In the American $(n=3)$ and Nepalese $(n=4)$, the frequency was $B>0$ with the absence of other blood groups. These results contrasted with previous results and which showed a higher frequency of $\mathrm{O}[9,50,53,54,63]$. The discrepancy is because they do not represent the whole population. In the Nigerien $(n=12)$, the frequency was $B>O>A=A B$, but no previous results were found. In Chinese, participants $(n=2)$ had an AB blood group with the absence of other blood groups. This is in contrast to a previous work, which was either $A>O>B>A B$ or $\mathrm{O}>\mathrm{A}>\mathrm{B}>\mathrm{AB}$ [64]. The discrepancy is due to our participants' small number. In Filipino $(n=8)$, they had $\mathrm{AB}>\mathrm{B}=\mathrm{O}>\mathrm{A}$, which contrasts with previous work that reported $\mathrm{O}>\mathrm{A}>\mathrm{B}>\mathrm{AB}$. The discrepancy is because they do not represent the whole population [65]. The Turkish $(n=35)$, Palestinian $(n=68)$, Syrian $(n=430)$, Lebanese $(n=12)$, Egyptian $(n=1130)$, and Afghan $(n=74)$ showed frequency of $A>O>B>A B$. In Turkish, Syrian, and Egyptian, our results agree with previous studies [13, 66-69]. In Palestinian and Lebanese previous works, the frequency was $\mathrm{O}>\mathrm{A}>\mathrm{B}>\mathrm{AB}$ in some regions and $\mathrm{A}>\mathrm{O}>\mathrm{B}>\mathrm{AB}$ in other regions [70-72]. Our results disagree with previous results in the Afghan, which was of $\mathrm{O}$ or $\mathrm{B}$ or $\mathrm{O}=\mathrm{B}$ but not of $\mathrm{A}[73]$. This may because they do not represent the whole population. In Ethiopian participants, both $\mathrm{A}$ and $\mathrm{O}$ had equal frequency. This agrees with previous results, which found some areas with a higher frequency of $A$ and other of $O[15,74]$. The Chadian $(n=9)$, French $(n=1)$, Tunisian $(n=6)$, Cameroonian $(n=3)$, and British $(n=2)$ all had a higher frequency of blood group A which was followed by $\mathrm{O}$ or $\mathrm{AB}$ or equal to $\mathrm{B}$ or absent of other blood groups. This agrees with France and contrasts with Cameron, Tunisia, and England, which reported $\mathrm{O}>\mathrm{A}>\mathrm{B}>\mathrm{AB}$ $[16,75-77]$. The discrepancy because they do not represent the whole population. In the Chadian, no previous works were found. Of all populations studied, $46.8 \%$ were O, $28.8 \% \mathrm{~A}, 19.5 \% \mathrm{~B}$, and $4.9 \% \mathrm{AB}$. This is in agreement with previous results, which stated that the $\mathrm{O}$ allele is $(63 \%), \mathrm{A}(21 \%)$, and $\mathrm{B}(16 \%)$ [78]. The blood group A, B, AB, and O of the Saudi population had a significant or no significant 
difference when compared to other people, (Figures1). The presence or absence of significance is due to the variations in the blood group's higher frequency. The variations are due to genetic and environmental factors. Also, the ABO blood group frequency may play a role in human disease [79]. The Rh-positive was predominant, and the $\mathrm{Rh}$-negative ranged from $3.2 \%$ to $66.7 \%$. The absence of Rh-negative in Indonesian, Malaysian, Thai, and Filipino agree with studies, which reported $<1 \%$ of Rh-negative [38, 44, 49, 8082]. The higher negativity in Tunisian, Chinese, and Cameroonian is due to their small number. All over the world, 5-11\% are Rh-negative except Britain and the USA, 15 and $17 \%$, respectively [83].

\section{Limitation of the study}

Some of the nationalities in our work had few numbers of participants, which need further studies to confirm our results.

\section{Conclusion:}

In Makkah city, the higher frequency of ABO blood group in Saudi and non -Saudi people is $\mathrm{O}$ followed by $\mathrm{A}$, then $\mathrm{B}$, and $\mathrm{AB}$. The Rh-positive is predominant, and $8.4 \%$ of the participants are negative. The encouragement of blood donation is essential for providing suitable blood storage for individuals in need. We recommendations further studies are needed to be performed on the $\mathrm{ABO}$ and $\mathrm{Rh}$ genes frequencies and their alleles in Makkah city.

\section{Conflict of Interest}

None

Funding

None

\section{References}

1. Landsteiner K. Zur kenntnis der antifermentativen, lytischen und agglutinierenden wirkungen des blutserums und der lymphe. Zentbl. Bakt. 1900;27:353-416.

2. DesCasterllo A, Sturli A. Uber die Isoagglutinine im Serum gesunder und kranker menschen. Mfinch Med Wschar. 1902;49:1090-1095.

3. O'Donghaile D, Jenkins P, McGrath R T, Preston L, Field SP, Ward SE, et al. Expresser phenotype determines $\mathrm{ABO}(\mathrm{H})$ blood group antigen loading on platelets and von Willebrand factor. Scientific Reports. 2020;10:18-366.

4. Franchini M, Lippi G. The intriguing relationship between the ABO blood group: cardiovascular disease, and cancer. BMC Medicine. 2015;13:7. DOI 10.1186/s12916-014-0250-y.

5. De Mattos LC. Structural diversity and biological importance of $\mathrm{ABO}, \mathrm{H}$, Lewis and secretor histo-blood group carbohydrates. Rev bras hematol hemoter. 2016;38(4):331-340.

6. EL Wafi M, EL Housse H, Nourichafi N, Bauisk K, Benajiba M, Habti N. Prevalence of weak Antigen D among Antigen $\mathrm{D}$ Negative $\mathrm{C} / \mathrm{E}$ and donors in Morocco. International Journal of Blood Transfusion and Immunohaematology. 2016;6(1): 3-6.

7. Alabdulmonema W, Shariqb A, Alqossayir F, AbaAlkhail FM, Al-Musallamd AY, Alzaaqi FO, et al. Sero-prevalence $\mathrm{ABO}$ and $\mathrm{Rh}$ blood groups and their associated Transfusion-Transmissible Infections among Blood Donors in the Central Region of Saudi Arabia. Journal of Infection and Public Health. 2020; 13:299-305.

8. Davison GM, Hendrickse HL, Matsha TE. Do Blood Group Antigens and the Red Cell Membrane Influence Human Immunodeficiency Virus Infection. Cells. 2020;9:845. doi:10.3390/cells9040845.

9. Groot HE, Villegas Sierra LE, Said MA, Lipsic E, Karper JC, der Harst PV. Genetically Determined ABO Blood Group and its Associations with Health and Disease. Arterioscler Thromb Vasc Biol. 2020;40:830-838.

10. Zietz M, Zucker J, Tatonetti NP. Associations between blood type and COVID-19 infection, intubation, and death. Nature communications. 2020; 11:5761 https://doi.org/10.1038/s41467-020-19623-X 11. Furuya K, Nakajima H, Sasaki Y, Urita Y. An examination of co-infection in acute gastroenteritis and histo-blood group antigens leading to viral infection susceptibility. Biomedical reports 2016;4: 331-334.

12. Cooling L. Blood Groups in Infection and Host Susceptibility. Clin Microbiol Rev. 2015 Jul;28(3):801-870. doi: 10.1128/CMR.00109-14.

13. Gündem NS, Atas E. Distribution of ABO and Rh Blood Groups among Patients Admitted to a Gynaecology, Obstetrics and Children Hospital in Konya, Turkey. Journal of Clinical and Diagnostic Research. 2019;13(3): EC01-EC04.

14. Hamed CT, Bollahi MA, Abdelhamid I, Mahmoud M, Ba B, Ghaber S, et al. Frequencies and ethnic distribution of $\mathrm{ABO}$ and $\mathrm{Rh}$ (D) blood groups in Mauritania: results of first nationwide study. Int $\mathbf{J}$ Immunogenet. 2012;39 (2):151-154.

15. Fufa, AW, Debelo DG. Distribution of ABO and $\mathrm{Rh}$ (D) blood groups among students attending secondary and preparatory schools in Bote town, Oromia national regional state, Ethiopia. Int. J. Sci. Technol. Educ. Res. 2019;10(1):1-8.

16. Ndoula ST, Noubiap JJN, Nansseu JRN, Wonkam A. Phenotypic and allelic distribution of the ABO and Rhesus (D) blood groups in the Cameroonian population. Int J Immunogenet. 2014;41(3):206-210. 17. Dewan G. Comparative frequency and allelic distribution of $\mathrm{ABO}$ and $\mathrm{Rh}(\mathrm{D})$ blood groups of major tribal communities of southern Bangladesh with general population and their determinants. Egypt J Med Hum Genet. 2015;16(2):141-147. 
18. RAI J., SINGH B. Distribution of ABO Blood Groups and Rhesus factor Percentage Frequencies Amongst the Populations of Sikkim, India. Proc Indian Natn Sci Acad. 2017;83: 217-222.

19. Radia, A, Ghita B, Hajar S, Hicham Y, Mustapha AA, Mohamed C. Prevalence of Blood Groups at the Blood Transfusion Center at the Military Hospital Avicenna of Marrakech. American Journal of Laboratory Medicine. 2019;4(6): 101-104.

20. Doku GN, Agbozo WK, Annor RA, Kisseh GD, Owusu MA. Frequency of ABO/Rhesus (D) Blood Groupings and Ethnic Distribution in the GreaterAccra Region of Ghana, Towards Effective Blood Bank Inventory. Int J Immunogenet. 2019;46(2):6773.

21. Smith S, Okai I, Abaidoo CS, Acheampong E. Association of ABO Blood Group and Body Mass Index: A Cross-Sectional Study from a Ghanaian Population. Journal of Nutrition and Metabolism. 2018;45 (8050152): https://doi.org/10.1155/2018/8050152.

22. Rao C, Shetty J. Frequency of ABO and Rh D blood groups in Dakshina Kannada district of Karnataka - a study from rural tertiary care teaching hospital in south India. NUJHS. 2014;4(3):57-60. ISSN 2249-7110.

23. Elsayid M, Aseeri YY, Al Saqri F. Alanazi A, Qureshi S. A Study of Prevalence of Blood Group of Saudi Patients in King Abdulaziz Medical CityRiyadh. Science Journal of Public Health. 2015;3(4):559-562.

24. Al-Noaemi MC, Daghriri HA. The Significant High Prevalence of Blood Group ' $\mathrm{O}$ ' in Yam Tribe of Najran City, the South Province of KSA. Blood Res Transfus J. 2018;2(1):1-5.

25. Eweidah MH, Rahiman S, Ali H, Al-Shamary AM. Distribution of $\mathrm{ABO}$ and Rhesus (RHD) Blood Groups in Al-Jouf Province of the Saudi Arabia. Anthropologist. 2011;13(2): 99-102.

26. Junainah E, Al-Amoudi S, Junainah J, El-ficki Y, baothman E, andijani A, et al Prevalence of ABO and $\mathrm{Rh}$ Blood Groups in Saudi Arabian Population. Life Science Journal. 2016;13(2):69-73.

27. Amal Zaghloul, Anas M Aljoaid, Duaa S Balkhi, Leena A Alharthi, Nasir A Alsubi, Ranin O Algethami, et al . Frequency of ABO blood groups in the Makkah city and their association with diseases. IAJPS. 2019;06 (01):551-557.

28. Moussa S, Al-zaylai F, Alnawmasi MO, Aljarwan MS, 1shammari HA, Alrashedi LM, et al. Pattern of distribution of $\mathrm{ABO}$ and Rhesus (RH) blood groups in hail province, Saudi Arabia. International Journal of Medical and Health Research. 2018;4(3): 166-170.

29. Chun S, Ryu MR, Yeon Cha S, Young Seo J, Duck Cho D. ABO Mistyping of cis-AB Blood Group by the
Automated Microplate Technique. Transfus Med Hemother. 2018;45(1):5-10. doi: 10.1159/000475506. 30. Harel VS, Pawar SG, Mahajan KD, Palaskar SG, More BP and Kulkarni KV. The Efficiency and Specificity of Matrix Gel Method from the Forensic Point of View, in Determination of ABO Blood Grouping and Rhesus Factor. Journal of Forensic Science \& Criminology. 2018; 6(1):1-9. ISSN: 23489804.

31. Xu L, Li H, Yang S, Zeng W, Gan S, Chen X, et al. Interference in the indirect antiglobulin test and direct antiglobulin test from rheumatoid factor. Journal of International Medical Research. 2019; 48(3):1-11.

32. Zaghloul A, Saudy N, Bajuaifer N, Aldosari MS, Sunqurah AH, Jei DR, et al. Frequency of Iron Deficiency Anemia and beta Thalassemia Trait in Female Medical Students at Umm Al-Qura University in the Makkah Region. IAJPS. 2019;06 (01):10261034.

33. WHO. Who can give blood. Available from:https://www.who.int/campaigns/world-blood-

donor-day/2018/who-can-give-blood.[Accessed 30-62020].

34. AlSuhaibani E.S., Kizilbash N.A., Afshan K., Malik S..Distribution and clinal trends of the $\mathrm{ABO}$ and $\mathrm{Rh}$ genes in select Middle Eastern countries. Genetics and Molecular Research. 2015;14 (3):10729-10742.

35. Abbas AA. Frequency of ABO and Rh D Blood Groups among Sudanese Blood Donors Attending Central Blood Bank in Wad Medani, Gezira State, Sudan. Int J Med Res Prof. 2017;3(2):45-51.

36. Theron M, Cross N, Cawkill P, Bustamante LY, Rayner JC. An in vitro erythrocyte preference assay reveals that Plasmodium falciparum parasites prefer Type O over Type A erythrocytes. Scientific reports. 2018;8:8133. DOI:10.1038/s41598-018-26559-2.

37. Al-Nahari AM. Gene Frequencies of $\mathrm{ABO}$ and $\mathrm{Rh}$ (D) Blood Group Alleles in Five Yemeni Provinces. Al-Kufa University Journal for Biology. 2017;9(2):200-207.

38. Anuphun T, Srichai S, Sudwilia Y, Jenwitheesuk K, Phunikhom K. ABO and Rhesus Blood Group Distribution in Blood Donors, Blood Transfusion Centre, Faculty of Medicine, Khon Kaen University, Thailand. Srinagarind Med J. 2018;33(suppl).

39. Kuesap J, Na-Bangchang K. The Effect of ABO Blood Groups, Hemoglobinopathy, and Heme Oxygenase-1 Polymorphisms on Malaria Susceptibility and Severity. Korean J Parasitol. 2018;56(2):167-173.

40. Al Hroob AM, Saghir S A M, Almaiman AA, Alsalahi OSA, Al-Wajeeh AS, Al-Shargi OYA, et al. Prevalence and Association of Transfusion Transmitted Infections with $\mathrm{ABO}$ and $\mathrm{Rh}$ Blood Groups among Blood Donors at the National Blood 
Bank, Amman, Jordan. Medicina. 2020;56:701-711. doi:10.3390/medicina56120701.

41. Rawat S, BhagoraR, Hazari RS, Mane A, Kapoor $\mathrm{P}$, Patil A. Frequency and Distribution of $\mathrm{ABO}$ and Rhesus Blood Group of Blood Donors. JMSCR. 2019;7 (11):148-152.

42. Traore K, Konate S, Thera MA, Niangaly A, Ba A, Niare A,et al. Genetic polymorphisms with erythrocyte traits in malaria endemic areas of Mali. PLoS ONE. 2019;14(1):1-10.

43. Amin R, Susanto D, Naher L. Distribution pattern of $\mathrm{ABO}$ and $\mathrm{Rh}$ blood groups and their allelic frequencies among different ethnic groups in Malaysia. Asian Journal of Medical Sciences. 2015; 6(4):25-29.

44. Hajar CGN, Zefarina Z, Riffin NS, Mohammad TH, Hassan MN, Poonachi P, et al. Extended blood group profiles for Malays, Chinese, and Indians in peninsular Malaysia. Egyptian Journal of Medical Human Genetics. 2020; 21:51-60.

45. Ismail AS. Distributional Patterns of ABO Blood Grouping and Rhesus Factor: Retrospective CrossSectional Study in Somali Regional Blood Bank. American Journal of Laboratory Medicine. 2019;4(2):48-52.

46. Wah ST, Chi SN, Kyaing KK, Khin AA, Aung T. Serological Detection of Rh-Del Phenotype among Rh-Negative Blood Donors at National Blood Center, Yangon, Myanmar. Advances in Hematology. 2020;2(3482124):5.

https://doi.org/10.1155/2020/3482124

47. Suwito BE, Kalanjati VP, Abdurachman. Blood type and blood pressure correlations to body mass index in young adults. Fol Med Indones. 2020;56(3):203-207.

48. Musa AU, Ndakotsu MA, Abdul-Aziz H, Kilishi A, Aliyu I. Distribution of ABO and Rhesus blood group systems among blood donors in Sokoto North-western Nigeria. J Appl Hematol. 2015;6:136138.

49. Marlentine M, Jusuf NK, Muis K. The relationship between $\mathrm{ABO}$ blood group typing with tinea corporis and or tinea cruris in Tanjung Gusta Prison, MedanIndonesia. Bali Medical Journal (Bali Med J). 2019;8(1):303-306.

50. Ugwu NI. Pattern of ABO and Rhesus blood group distribution among students of Ebonyi State University, Abakaliki, South Eastern Nigeria. Asian Journal of Medical Sciences. 2016;7(1):101-104.

51. Butt SJ, Malik S, Malik H, Butt AJ. ABO and Rhesus Blood Grouping in Voluntary Blood Donors and its gender association. PJMHS. 2018;12(1):268271.

52. Ullah S, Ahmad T. Distribution of ABO and Rh (D) Blood Groups in the Population of District Dir
Lower,Khyber Pakhtunkhwa Pakistan. World Applied Sciences Journal. 2015;33(1):123-135.

53. Matough FA, Alhoderi J, Abdullkader A, Abdullsalam J, Alwahaibi N. The frequency of ABO and Rhesus blood groups phenotypes, genotypes from Sebha city of Libya. JOPAS. 2019;18 (1):17-22.

54. Nabil B, Bounab S, Benazzi L, Yahiaoui M. Genetic polymorphisms of blood donors in Algeria through blood groups ABO, RH, and Kell. Transfus Clin Biol. 2020 Feb;27(1):43-51.

55. Sawadogo S, Nebie K, Millogo T, Kafando E, Sawadogo AG, Dahourou H, et al. Distribution of $\mathrm{ABO}$ and RHD blood group antigens in blood donors in Burkina Faso. Int J Immunogenet. 2018; 46 (1):16.

56. Ad'hiah AH, Allami RH, Mohsin RH, Abdullah MH, AL-Sa'ady AJR, Alsudani MY. Evaluating of the association between $\mathrm{ABO}$ blood groups and coronavirus disease 2019 (COVID-19) in Iraqi patients. Egyptian Journal of Medical Human Genetics. 2020; 21:50-55.

57. Almadhi MA, Abdulrahman A, Alawadhi A, Rabaan A, AlQahtani M. The effect of ABO blood group and antibody class on the risk of COVID-19 infection and severity of clinical outcomes. medRxiv preprint. doi: https://doi.org/10.1101/2020.09.22.20199422;

58. Canadian Blood Services (2016). Canadian blood services. Available from https://www.blood.ca/en

59. Fazlović A,Hamidović H, Avdić A ,Jusić A. The analysis of blood type distribution of the $\mathrm{ABO}$ and $\mathrm{Rh}$ system in the population of Tuzla Canton (Bosnia and Herzegovina). 10th International Scientific Conference: Science and Higher Education in Function of Sustainable Development. 2017.

60. Roy B, Banerjee I, Sathian B, Mondal M, Saha CG. Blood Group Distribution and Its Relationship with Bleeding Time and Clotting Time: A Medical School Based Observational Study among Nepali, Indian and Sri Lankan Students. Nepal Journal of Epidemiology. 2011;1(4):135-140.

61. Loscertales MP, Brabin BJ. ABO phenotypes and malaria related outcomes in mothers and babies in The Gambia: a role for histo-blood groups in placental malaria. Malaria Journal. 2006;5:72-77.

62. Mederos LEA, Álvarez PB. Population Genetics for the ABO Blood System in a Population with Endemic Malaria. CCM. 2014;18(1):9-17.

63. Niroula DR, Jha MK, Limbu P, Pokhre I, Yadav SK, Mukhopadhyay S. Ethnic variations of blood groups in a Medical College of Eastern Nepal. Kathmandu Univ Med J. 2018;61(1):18-22.

64. Liu J, Zhang S, Wang Q, Shen H, Zhang Y, Liu M. Frequencies and ethnic distribution of $\mathrm{ABO}$ and $\mathrm{RhD}$ blood groups in China: a population-based cross 
sectional study. BMJ Open. 2017;7:e018476. doi:10.1136/ bmjopen-2017-018476.

65. Barrera Jr. Phenotypic Distribution of ABO Blood Groups between Cosmopolitan and Regional Population of Lucban, Quezon. Tilamsik. 2018;10(1). Philippine E journal.

66. Salduz ZIY, Çetin G, Karatoprak C, Özder A, Bilginç M, Gültepe I, et al.ABO and Rh Blood Group Distribution in İstanbul Province (Turkey). İstanbul Med J. 2015; 16: 98-100.

67. Al-Ani L, Mahmood HM, Abdulhaleem N. Genetically Determined ABO and (Rh) Rhesus Blood Groups and Their Associations with Diabetes Mellitus. Sys Rev Pharm. 2020;11(4):604 -608.

68. Swelem O, Goubran F, Younis S, Kamel N. ABO, $\mathrm{RH}$ phenotypes and kell blood groups frequencies in an Egyptian population. Hematol Transfus Int J. 2018;6(2):71-75.

69. Abdelmonem M, Fyala A, Boraik A, Shedid M, Mohamed AH, Abdel-Rhman M. Distribution of Blood Types and ABO Gene Frequencies in Egypt. Am J Clin Pathol. 2019;152:S151-S155.

70. Alsadi R. Personality Traits and Their Relationship with Blood Groups among of Palestinian University Students. International Journal of Psychology and Behavioral Sciences. 2020;10(2):34-42.

71. Skaik YA, Alhawary AS, Shbair AS, Hamouda BB. Frequency of $\mathrm{ABO}$ and $\mathrm{Rh}$ (D) blood groups in five Governates in Gaza -Strip. Pak J Med Sci. 2007;23(6):924-927.

72. Tarhini M, Kazan HF, Hijazi R, Raee A, Youness $\mathrm{M}$, Ezzedine M, et al. Prevalence of $\mathrm{ABO}$ and $\mathrm{Rh}$ blood group systems over the entire Lebanese population. Asian Journal of Science and Technology. 2018; 9(7):8440-8443.

73. Mazières S., Temory S. A., Vasseur H., Gallian P., Di Cristofaro J., Chiaroni J. Blood group typing in five Afghan populations in the North Hindu-Kush region: implications for blood transfusion practice. Transfusion Medicine Wiley. 2013;23(3):167-174.

74. Golassa L, Tsegaye A, Erko B, Mamo H. High rhesus $(\mathrm{Rh}(\mathrm{D})$ negative frequency and ethnic-group based $\mathrm{ABO}$ blood group distribution in Ethiopia. BMC Res Notes. 2017;10:330. DOI 10.1186/s13104-0172644-3.

75. Yalaoui S, Fakhfakh R, Tritar F, Chaouch N, Mestiri T, et al. ABO blood groups and risk of covid19. La Tunisie Medicale. 2020;98(12):888-891.

76. Joint United Kingdom (UK) Blood Transfusion and Tissue Transplantation Services Professional Advisory Committee .Transfusion Handbook (2) The ABO system. Available from: http://www.transfusionguidelines.org/transfusionhandbook/2-basics-of-blood-groups-andantibodies/2-4-the-abo-system.[Accessed 10-1-2021].
77. Borghese B, Chartier M, Souza C, Santulli P, Pillet MCL, de Ziegler D, et al. ABO and Rhesus Blood Groups and Risk of Endometriosis in a French Caucasian Population of 633 Patients Living in the Same Geographic Area. BioMed Research International. 2014;4(618964):6.

78. Distribution of blood types.Available from: https://www2.palomar.edu/anthro/vary/vary_3.htm. [Accessed on 1-2-2021].

79. Anifowoshe AT, Owolodun OA, Akinseye KM, Iyiola OA, Bolaji Fatai Oyeyemi BF. Gene frequencies of $\mathrm{ABO}$ and $\mathrm{Rh}$ blood groups in Nigeria: A review. The Egyptian Journal of Medical Human Genetics. 2017;18:205-210.

80. Dewi I, Dalimoenthe NZ, Tjandrawati A, Suraya N. Proportion of Rhesus Blood Phenotypes at the Blood Donor Unit in Bandung City. Indonesian journal of clinical pathology and medical laboratory. 2019;25(2):155-160.

81. Republic of the Philippines department of health. What is the most common blood type. Available from: https://doh.gov.ph/node/1447. [Accessed on 10-12021].

82. Jahanpour O, Pyuza JJ, Ntiyakunze EO, Mremi A, Shao ER. ABO and Rhesus blood group distribution and frequency among blood donors at Kilimanjaro Christian Medical Center, Moshi, Tanzania. BMC Res Notes. 2017;10:738-742.

83. Apecu RO, Mulogo EM, Bagenda F, Byamungu A. $\mathrm{ABO}$ and Rhesus (D) blood group distribution among blood donors in rural south western Uganda: a retrospective study. BMC Res Notes. 2016;9:513-516. 